\title{
Correction to: Residual feed intake phenotype and gender affect the expression of key genes of the lipogenesis pathway in subcutaneous adipose tissue of beef cattle
}

Clare McKenna ${ }^{1,2}$, Richard K. Porter ${ }^{2}$, Kate A. Keogh ${ }^{1}$, Sinead M. Waters ${ }^{1}$, Mark McGee ${ }^{1}$ and David A. Kenny ${ }^{1 *}$

\section{Correction}

In the original publication of this article [1], some errors

in Table 4 need to be corrected as below:

"Creating, umil/L" should be "Creatine, umol/L"

"Glucose, nmlo/L" should be "Glucose, $\mathrm{nmol} / \mathrm{L}$ "

"Urea, nmo/L" should be "Urea, nmol/L"

The original publication has been corrected.

\section{Author details}

${ }^{1}$ Animal and Bioscience Research Department, Teagasc Grange, Dunsany, Meath C15 PW93, Ireland. ${ }^{2}$ School of Biochemistry \& Immunology, Trinity

College Dublin, Dublin 2 D02 R590, Ireland.

Received: 19 October 2018 Accepted: 22 October 2018

Published online: 07 November 2018

\section{Reference}

1. McKenna, et al. Residual feed intake phenotype and gender affect the expression of key genes of the lipogenesis pathway in subcutaneous adipose tissue of beef cattle. J Anim Sci Biotechnol. 2018;9:68 https://doi. org/10.1186/s40104-018-0282-9.

\footnotetext{
* Correspondence: david.kenny@teagasc.ie

${ }^{1}$ Animal and Bioscience Research Department, Teagasc Grange, Dunsany, Meath C15 PW93, Ireland

Full list of author information is available at the end of the article
} 